\title{
Comparative Studies on Removal of Chromium (VI) from Monocotyledon (Allium cepa) Tunic and Dicotyledon Plant (Tabebuia aurea)
}

\author{
Krishnamurthy Saranya*, Marimuthu Thirumarimurugan \\ Department of Chemical Engineering, Coimbatore Institute of Technology, \\ Coimbatore-641014, Tamilnadu, India
}

Received: 27 May 2014

Accepted: 3 September 2014

\begin{abstract}
In the present study, the influence of various important parameters such as $\mathrm{pH}$, adsorbent dosage, shaking velocity, and concentration of $\mathrm{Cr}(\mathrm{VI})$ on the adsorbent Allium cepa tunic and Tabebuia aurea capacity were investigated. Isotherms such as Langmuir, Freundlich, Temkin, and Dubinin-Radushkevich and kinetic studies were done. The maximum removal efficiencies were obtained at $75 \mathrm{rpm}$ for both monocot and dicot plant species. At $\mathrm{pH} 3$, the adsorbent T. aurea gives $87 \%$ A. cepa, and at $\mathrm{pH} 5$ gives $96.4 \%$ removal of $\mathrm{Cr}(\mathrm{VI})$ from aqueous solution containing the concentration of $50 \mathrm{mg} / \mathrm{L}$ with the adsorbent dosage of $10 \mathrm{~g} / \mathrm{l}$. From this study T. aurea maximum percentage removal were noticed at $\mathrm{pH}$ 5, adsorbent: $10 \mathrm{mg} / \mathrm{L}$, shaking period: $75 \mathrm{rpm}$, initial concentration: $150 \mathrm{mg} / \mathrm{L}$ were as maximum percentage removal for $A$. cepa were obtained at $\mathrm{pH} 3$, adsorbent: $10 \mathrm{mg} / \mathrm{L}$, shaking period: $75 \mathrm{rpm}$, initial concentration: $150 \mathrm{mg} / \mathrm{L}$. At the end of the experiment both Monocotyledon (Allium cepa) tunic and Dicotyledon plant (Tabebuia aurea) gave a better removal percentage at high concentrations.
\end{abstract}

Keywords: chromium (VI), Allium cepa tunic, T. aurea, shaking period

\section{Introduction}

One of the major reasons for pollution of water and soil is the rapid growth of industries. Effluents from industries are the main sources of water contamination. Discharged concentrations of many criteria metals in the aquatic environment have been reduced over the last few decades, through the implementation of stringent Environmental Quality Standards. But heavy metals are highly toxic even at low concentrations and can accumulate in living organisms, causing several disorders and diseases [1, 2]. In India, many industrial tannery units are spread mostly across

*e-mail: ksaranya31@gmail.com
Tamil Nadu, especially at Chennai - a major trading center for hides and skins. Heavy metals are non-biodegradable and can lead to accumulation in living organisms, causing various diseases and disorders [3]. There are numerous methods for the removal of these heavy metal ions from wastewater streams, including chemical precipitation [4, 5], reverse osmosis [6], filtration methods [7], and electro coagulation $[8,9]$.

Biosorption is generally defined as the accumulation of metals by biological materials without active uptake, and can be considered a collective term for a number of passive accumulation processes that may include ion exchange, coordination, complexation, chelation, adsorption, and micro precipitation $[10,11]$. Conventional methods of removing toxic 
heavy metal ions include chemical precipitation, chemical oxidation or reduction, filtration, ion exchange, electrochemical treatment, application of membrane technology, and evaporation recovery. However, these processes have considerable disadvantages such as incomplete metal removal, expensive equipment and monitoring systems, high reagent or energy requirements, generation of toxic sludge, and other waste products that require disposal [12]. Based on the literature, we have chosen both Monocotyledon (Allium сера) tunic and Dicotyledon plant (Tabebuia aurea), which they have not used in their experiments.

\section{Materials and Methods}

\section{Selection of the Plant}

Tabebuia aurea (dicotyledon) leaves were collected at the Coimbatore Institute of Technology, and the tunic of Allium cepa (Monocotyledon) was collected from the local market at Hosur, Krishnagiri district, Tamilnadu. These monocotyledon tunic and dicotyledon plants were selected as biosorbents for the removal of chromium (VI) ion in this study.

\section{Preparation of Adsorbents}

Tabebuia aurea leaves and tunic of Allium cepa were washed thoroughly in running water to remove impurities and any adhering particles. The leaves were dried at room temperature for 20 days until they became crisp. The dried leaves were crushed and blended to powder and sieved. $1.676 \mathrm{~mm}$ mesh size particle were collected and it was stored in an airtight container for further use to avoid contact with moisture in the atmosphere.

\section{Preparation of $\mathrm{Cr}(\mathrm{VI})$ and Metal Analysis}

Stock solution of chromium (VI) was prepared by dissolving $2.82 \mathrm{~g}$ of potassium dichromate in $1 \mathrm{~L}$ of distilled water. The working solution was prepared by diluting the stock solution. Chromium was analyzed using the UV Spectrophotometric method with 1, 5-diphenycarbazide at $540 \mathrm{~nm}$.

\section{Batch Experiments \\ Effect of Shaking Velocity}

$1 \mathrm{~g}$ of each leaf powder (T. aurea and A. cepa) was added to the concentration of $50 \mathrm{mg} / \mathrm{L}$. Flasks were maintained at different shaking velocities such as 75, 150, and $200 \mathrm{rpm}$ in an orbital shaker. Contact time ranged from 0-5 hours.

\section{Effect of $p H$}

Effects of $\mathrm{pH}$ were conducted by using $50 \mathrm{mg} / \mathrm{L}$ of chromium (VI) concentration with an adsorbent dosage of $1 \mathrm{~g} / \mathrm{L}$ and contact time of 5 hours.

\section{Effect of Concentration}

$1 \mathrm{~g}$ of adsorbent to different chromium (VI) concentrations $(50,75$, and $150 \mathrm{mg} / \mathrm{L})$, at $\mathrm{pH} 5$ for $T$. aurea and at $\mathrm{pH} 3$ for $A$. cepa respectively, contact time ranged from $0-5$ hours.

\section{Effect of Dosage}

The effect of adsorbent dosage level on percent removal of chromium (VI) was studied using concentrations of $50 \mathrm{mg} / \mathrm{L}, \mathrm{pH}$ 5, 3 for T. aurea and A. cepa, respectively, and the amount of adsorbent used for this study was $5 \mathrm{~g}, 10 \mathrm{~g}$, and $15 \mathrm{~g}$ with contact time ranging from 0-5 hours.

\section{Calculation of Metal Uptake}

(i) The amount of metal adsorbed by the adsorbent is calculated by:

$$
q=\frac{(C-C e) V}{M}
$$

...where:

$q-\quad$ amount of metal ion adsorbed in $\mathrm{mg} / \mathrm{g}$

$C, C_{e}$-initial and final metal ion concentrations in $\mathrm{mg} / \mathrm{L}$

$V-\quad$ volume of metal ion solution in 1

$M-\quad$ mass of adsorbents in $\mathrm{g}$

(ii) The percentage of removal of metal ions was determined by:

$$
\% \text { Removal }=\frac{C-C e}{C} \times 100
$$

\section{Adsorption Isotherms}

Isotherm studies at equilibrium constant concentration of metals was investigated using the two most widely used model equations of Freundlich [13], and Langmuir and Temkin isotherms (Figs. 1-3) [14, 15], DubininRadushkevich [16].

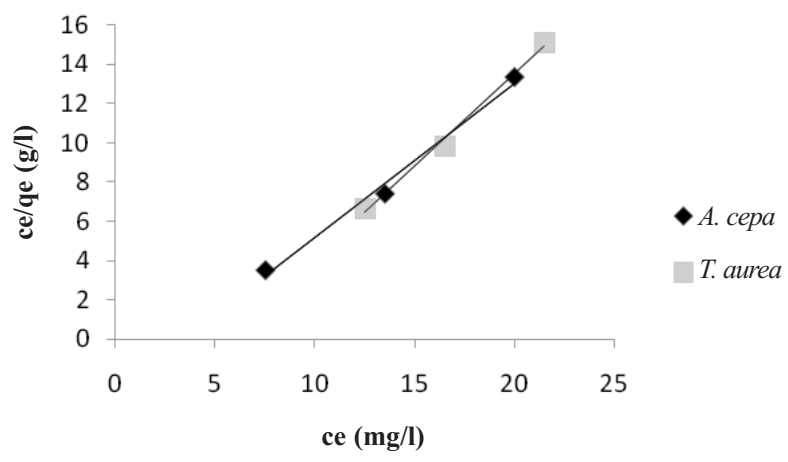

Fig. 1. Langmuir isotherm. 


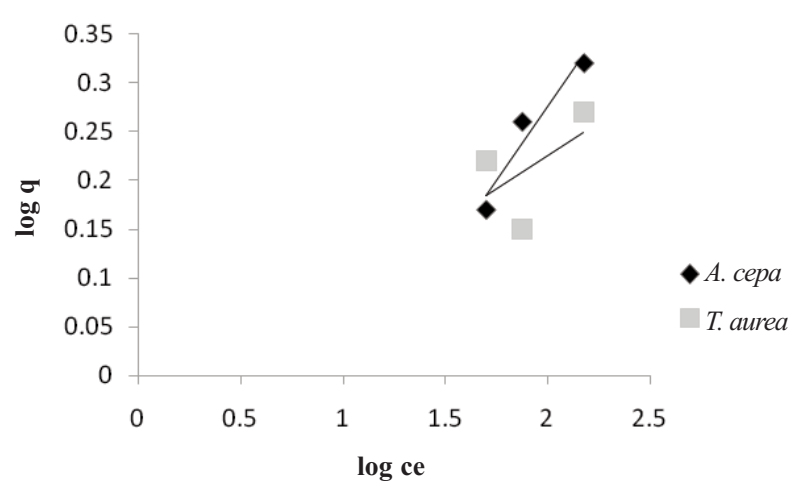

Fig. 2. Freundlich isotherm.



Fig. 3. Temkin isotherm.

\section{Kinetic Studies}

\section{Pseudo First-Order Model}

The possibility of adsorption data following Lagergren pseudo first-order kinetics (Figs. 4-6) is given by:

$$
\frac{d q}{d t}=K_{I}\left(q_{e}-q\right)
$$

Integrating the above equation with respect to integration conditions $q=0$ to $q=q$ at $t=0$ to $t=t$, the kinetic rate expression becomes:

$$
\log \left(q_{e}-q\right)=\log q_{e}-\frac{K_{1}}{2.3} t
$$

The pseudo first-order rate constant $K_{1}$ can be obtained from the slope of plot between $\log \left(q_{e}-q\right)$ versus time, $t$.

\section{Pseudo-Second Order Model}

A pseudo second-order model can be used to explain the adsorption kinetics (Figs. 7 and 8). This model is based on the assumption that the adsorption follows second-order chemisorptions. The pseudo second-order model can be expressed as:

$$
\frac{d q}{d t}=K_{2}\left(q_{e}-q\right)^{2}
$$

Separating the variables from the above equation:

$$
\frac{d q}{\left(q_{e}-q\right)^{2}}=K_{2} d t
$$

Integrating Eq. (6) for the boundary conditions $q=0$ to $q=q$ at $t=0$ to $t=t$, simplifies to:

$$
\frac{t}{q}=\frac{1}{k_{2} q_{e}^{2}}+\frac{1}{q_{e}} t
$$

...where $t$ is the contact time $(\mathrm{min})$, and $q_{e}(\mathrm{mg} / \mathrm{g})$ and $q(\mathrm{mg} / \mathrm{g})$ are the amount of the solute adsorbed at equilibrium and at any time, $t$. A plot between $t / q_{t}$ versus $t$ gives the value of the constant $K_{2}\left(\mathrm{~g} \cdot(\mathrm{mg} \cdot \mathrm{min})^{-1}\right)$, and also $q_{e}(\mathrm{mg} / \mathrm{g})$ can be calculated.



Fig. 4. Dubinin-Radushkevich isotherm.



Fig. 5. Pseudo first-order kinetics for T. aurea.

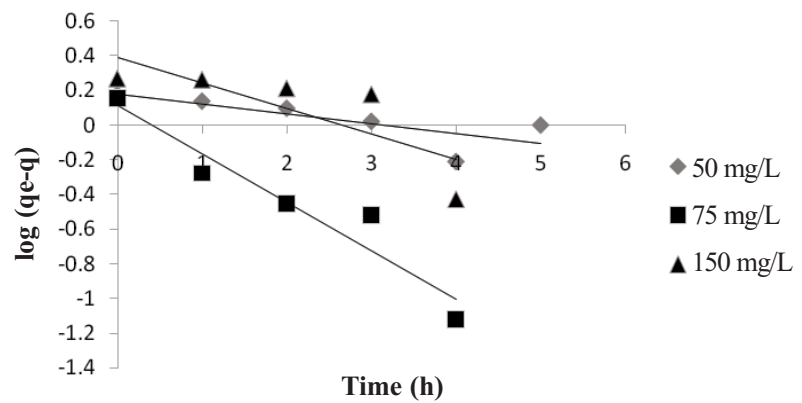

Fig. 6. Pseudo first-order kinetics for A. cepa. 
Table 1. Effect of various Shaking periods on removal of $\mathrm{Cr}(\mathrm{VI})$ using $T$. aurea and A. cepa.

\begin{tabular}{|c|c|c|}
\hline $\begin{array}{c}\text { Shaking } \\
\text { period }\end{array}$ & $\begin{array}{c}\text { T. auria } \\
\text { \% removal of } \mathrm{Cr}(\mathrm{VI})\end{array}$ & $\begin{array}{c}\text { A. cepa } \\
\text { \% removal of } \mathrm{Cr}(\mathrm{VI})\end{array}$ \\
\hline 75 & 92 & 93 \\
\hline 100 & 89 & 90 \\
\hline 125 & 84 & 83 \\
\hline 150 & 81 & 80 \\
\hline 175 & 80.2 & 75 \\
\hline 200 & 79 & 58 \\
\hline
\end{tabular}

\section{Results and Discussion}

\section{Effect of Shaking Period}

The maximum removal efficiencies were obtained at $75 \mathrm{rpm}$ for both T. auria and $A$. серa, the maximum adsorption capacities were found to be $92 \%$ and $93 \%$, respectively. The adsorptions were lowest at $200 \mathrm{rpm}$ for both $T$. auria and $A$. серa. Increasing the shaking speed shows a decline in the adsorption capacity (Table 1 and Fig. 9).

This effect can probably be attributed to the decrease in boundary layer thickness around the adsorbent particles, which results from increasing the degree of mixing. When the mixture was shaken, the solid particles moved around rapidly in the solution, and this increased the concentration of heavy metals near the surface of the solid particles, possibly to a level near that of the bulk concentration. Because heavy metal diffusion to the boundary layer between adsorbent particles and the surrounding solution would increase with increased shaking, the external mass transfer speed of the metals would increase and equilibrium would be reached more rapidly. This may occur because the high shaking speed provided sufficient additional energy to break newly formed bonds between the metal ions and the adsorbent surface [17].

\section{Effect of $\mathrm{pH}$}

Solution $\mathrm{pH}$ plays a major role in the bioadsorption of $\mathrm{Cr}(\mathrm{VI})$, and it could be related to the type and ionic state of the functional group present on the bioadsorbent surface [13].

At an initial $\mathrm{pH}$ value of 3 , adsorbent $A$. cepa gives $87 \%$ removal of $\mathrm{Cr}(\mathrm{VI})$ from aqueous solution containing the concentration of $50 \mathrm{mg} / \mathrm{L}$. from the speciation graph it was found that $T$. aurea gives maximum $96.4 \%$ removal of $\mathrm{Cr}(\mathrm{VI})$ from aqueous solution at $\mathrm{pH} 5$. T. aurea gives maximum percentage of removal when compared with $A$. cepa (Table 2 and Fig. 10). This implies that the dicot plant is more efficient in removal of chromium (VI) than the monocot plant.

More adsorption at acidic $\mathrm{pH}$ indicated that the lower $\mathrm{pH}$ resulted in an increase in $\mathrm{H}^{+}$ions on the adsorbent sur- face, which resulted in insignificantly strong electrostatic attraction between the positively charged adsorbent surface and chromate ions $[18,19]$.

\section{Effect of Concentration}

The adsorption of $\mathrm{Cr}(\mathrm{VI})$ was carried out at 50, 75, and $150 \mathrm{mg} / \mathrm{L}$ as Initial $\mathrm{Cr}(\mathrm{VI})$ ion concentration for a period of 5 hours at $\mathrm{pH} 5$ for $T$. aurea and $\mathrm{pH} 3$ for $A$. сера). Adsorbent amount used was $10 \mathrm{~g} / 1$. T. aurea and $A$. cepa shows $75 \%$ and $85 \%$ removal at $150 \mathrm{mg} / \mathrm{L}$ (Table 3 and Fig. 11).

The initial concentration provides an important driving force to overcome all mass transfer resistances of solutes between the aqueous and solid phases. The amount of $\mathrm{Cr}(\mathrm{VI})$ adsorbed on the biomass increased with initial concentration of the metal ions [11].



Fig. 7. Pseudo second-order kinetics for A. cepa.



Fig. 8. Pseudo second-order kinetics for T. aurea.



Fig. 9. Effects of various rpm on T. aurea and A. серa. 
Table 2. Effect of various $\mathrm{pH}$ on removal of $\mathrm{Cr}(\mathrm{VI})$ using T. aurea and A. cepa.

\begin{tabular}{|c|c|c|}
\hline $\mathrm{pH}$ & $\begin{array}{c}\text { T. auria } \\
\text { \% removal of } \mathrm{Cr}(\mathrm{VI})\end{array}$ & $\begin{array}{c}\text { A. cepa } \\
\text { \% removal of } \mathrm{Cr}(\mathrm{VI})\end{array}$ \\
\hline 3 & 87 & 87 \\
\hline 4 & 90 & 82 \\
\hline 5 & 96.45 & 80 \\
\hline 6 & 86 & 78 \\
\hline 7 & 76 & 76 \\
\hline
\end{tabular}

Table 3. Effect of various concentrations on removal of $\mathrm{Cr}(\mathrm{VI})$ using T. aurea and A. cepa.

\begin{tabular}{|c|c|c|}
\hline $\begin{array}{c}\text { Concentrations } \\
(\mathrm{mg} / \mathrm{L})\end{array}$ & $\begin{array}{c}\text { T. auria } \\
\text { \% removal of } \mathrm{Cr}(\mathrm{VI})\end{array}$ & $\begin{array}{c}\text { A. cepa } \\
\text { \% removal of } \mathrm{Cr}(\mathrm{VI})\end{array}$ \\
\hline 50 & 67 & 60 \\
\hline 75 & 57 & 73 \\
\hline 150 & 75 & 85 \\
\hline 50 & 67 & 60 \\
\hline
\end{tabular}

Table 4. Effect of various dosages on removal of $\mathrm{Cr}(\mathrm{VI})$ using T. aurea and A. cepa.

\begin{tabular}{|c|c|c|}
\hline $\begin{array}{c}\text { Dosage } \\
(\mathrm{ml})\end{array}$ & $\begin{array}{c}\text { T. auria } \\
\text { \% removal of } \mathrm{Cr}(\mathrm{VI})\end{array}$ & $\begin{array}{c}\text { A. cepa } \\
\text { \% removal of } \mathrm{Cr}(\mathrm{VI})\end{array}$ \\
\hline 5 & 80 & 90 \\
\hline 7 & 86 & 94 \\
\hline 10 & 92 & 95 \\
\hline 15 & 92 & 94 \\
\hline
\end{tabular}

\section{Effect of Dosage}

The percentage of $\mathrm{Cr}(\mathrm{VI})$ removal was found to be increased with an increase in the adsorbent amount from $5 \mathrm{~g} \cdot \mathrm{L}^{-1}$ to $15 \mathrm{~g} \cdot \mathrm{L}^{-1}$, respectively. The percentage removal of $\mathrm{Cr}(\mathrm{VI})$ with the amount of adsorbent and adsorption percentage was shown in Figs. 11 and 12. The increase in $\mathrm{Cr}(\mathrm{VI})$ removal was due to the increase in surface area and adsorption sites available for adsorption [2]. With adsorbent $15 \mathrm{~g} \cdot \mathrm{L}^{-1}$ at the concentration of $50 \mathrm{mg} \cdot \mathrm{L}^{-1}$ the $\%$ removal was found to be 92 and 94 for T. aurea and A. cepa, respectively (Table 4 and Fig. 12).

\section{Adsorption Equilibrium}

The adsorption equilibrium defines the distribution of a solute phase between the liquid phases and solid phases after the adsorption reaction reached equilibrium condition. In the present study, equilibrium studies were carried out at room temperature. The equilibrium data were analyzed using the following isotherm equations and the values are shown in Tables 5-7.

The isotherms such as Langmuir, Freundlich, Temkin [15], and kinetic studies were studied for T. aurea and A. cepa and the $\mathrm{R}^{2}$ were shown in Table 5 monocot plant A. cepa tunic shows better results than dicot plant $T$. aurea.

Dubinin-Radushkevich isotherm showed that the adsorption of chromium (VI) in T. aurea and A. cepa were physical adsorption. $\mathrm{R}^{2}$, and $\mathrm{E}$ (mean free energy) were shown in Table 5, Fig. 4.

The pseudo first-order rate constant $K_{1}$ can be obtained from the slope of plot between $\log \left(q_{e}-q\right)$ versus time, $t$ at the concentration of 50,75, and $150 \mathrm{mg} / \mathrm{L}$ for $T$. aurea and A. серa. The calculated $K_{1}$ values and their corresponding linear regression correlation coefficient values are shown in Tables 6 and 7 .

A plot between $t / q_{t}$ versus $t$ gives the value of the constant $K_{2}\left(\mathrm{~g} \cdot(\mathrm{mg} \cdot \mathrm{min})^{-1}\right)$, and also $q_{e}(\mathrm{mg} / \mathrm{g})$ can be calculated at the concentration of 50,75 , and $150 \mathrm{mg} / \mathrm{L}$ for $T$. aurea and $A$. cepa. The pseudo second-order rate constant $K_{2}$, the calculated $q_{e}$, value and the corresponding lin-



Fig. 10. Effect of various $\mathrm{pH}$ on T. aurea and A. cepa.

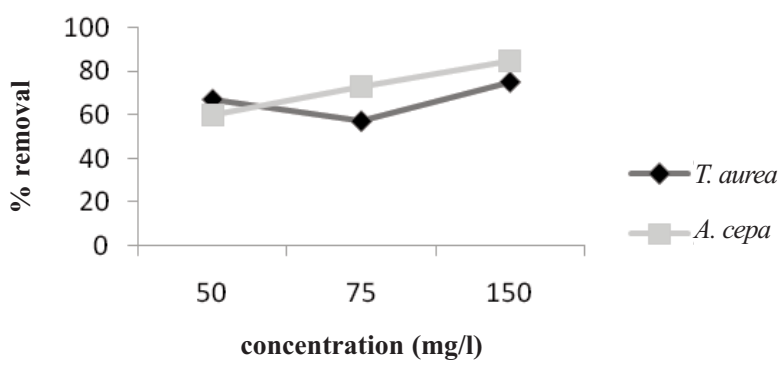

Fig. 11. Effect of various concentrations on T. aurea and A. cepa.

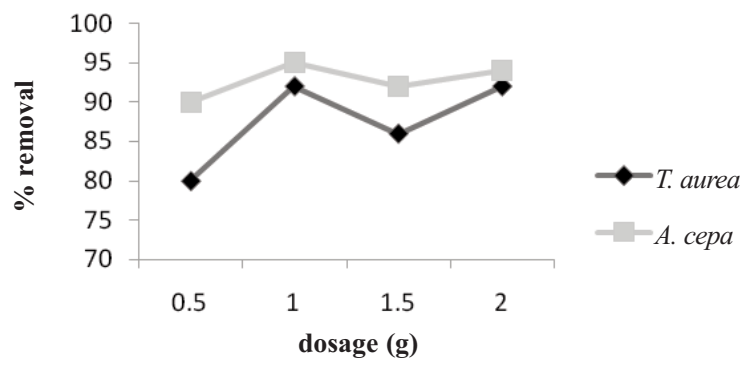

Fig. 12. Effect of various dosage on T. aurea and A. cepa. 
Table 5. Adsorption Equilibrium of Langmuir, Freundlich, Temkin and isotherm.

\begin{tabular}{|c|c|c|c|}
\hline Adsorbent & & & \\
\hline \multirow{12}{*}{ T. aurea } & \multicolumn{3}{|c|}{ Langmuir Isotherm } \\
\hline & $q_{m}(\mathrm{mg} / \mathrm{g})$ & $b(\mathrm{~L} / \mathrm{mg})$ & $\mathrm{R}^{2}$ \\
\hline & 1.006 & 0.177 & 0.994 \\
\hline & \multicolumn{3}{|c|}{ Freundlich Isotherm } \\
\hline & $K_{F}(\mathrm{mg} / \mathrm{g})$ & $n$ & $\mathrm{R}^{2}$ \\
\hline & 1.049 & 7.352 & 0.298 \\
\hline & \multicolumn{3}{|c|}{ Temkin Isotherm } \\
\hline & $A(\mathrm{~L} / \mathrm{g})$ & $b(\mathrm{~J} / \mathrm{mol})$ & $\mathrm{R}^{2}$ \\
\hline & 50.5 & 10.51 & 0.853 \\
\hline & \multicolumn{3}{|c|}{ Dubinin-Radushkevich Isotherm } \\
\hline & $\mathrm{R}^{2}$ & $K_{D R}\left(\mathrm{Mol}^{2} / \mathrm{KJ}^{2}\right)$ & $E(\mathrm{KJ} / \mathrm{mol})$ \\
\hline & 0.548 & 6187 & 0.0089 \\
\hline \multirow{11}{*}{ A. сера } & \multicolumn{3}{|c|}{ Langmuir Isotherm } \\
\hline & 1.269 & 0.294 & 0.990 \\
\hline & \multicolumn{3}{|c|}{ Freundlich Isotherm } \\
\hline & $K_{F}(\mathrm{mg} / \mathrm{g})$ & $n$ & $\mathrm{R}^{2}$ \\
\hline & 1.388 & 3.311 & 0.931 \\
\hline & \multicolumn{3}{|c|}{ Temkin Isotherm } \\
\hline & $A(\mathrm{~L} / \mathrm{g})$ & $b(\mathrm{~J} / \mathrm{mol})$ & $\mathrm{R}^{2}$ \\
\hline & 3.05 & 0.55 & 0.971 \\
\hline & \multicolumn{3}{|c|}{ Dubinin-Radushkevich Isotherm } \\
\hline & $\mathrm{R}^{2}$ & $K_{D R}\left(\mathrm{Mol}^{2} / \mathrm{KJ}^{2}\right)$ & $E(\mathrm{KJ} / \mathrm{mol})$ \\
\hline & 0.932 & 1408 & 0.0188 \\
\hline
\end{tabular}

ear regression correlation coefficient values $\mathrm{R}^{2}$ are given in Tables 6 and 7.

\section{Conclusions}

From the previous literature we compared the results of Gholami and Mahvi [2, 20], who reported that Dicotyledon plant species such as plataneus Orientalis leaves, plant Ulmus leaves and Acharya et al. [22] and the Tamarind wood gives maximum removal percentage of $5.01(\mathrm{mg} / \mathrm{g})$ $\left(\mathrm{pH}=7.0,24^{\circ} \mathrm{C}, 120 \mathrm{~min}\right), 0.9(\mathrm{mg} / \mathrm{g})\left(\mathrm{pH}=6.0,24^{\circ} \mathrm{C}\right.$, $60 \mathrm{~min}$ ), 22 to $82 \%$ at $50 \mathrm{mg} / \mathrm{l}$ initial feed concentration, respectively, whereas as $T$. aurea gives maximum removal of $92 \%$. In Monocotyledon plant species such as Sugarcanebagasse, Maizecob (Sharma, D. C) ricehulls (CiCi, Mechmet) 13.4 (mg/g), 13.8 (mg/g), 99-38\%, were as $A$. cepa gives maximum removal of $94 \%$.

From a comparison of the above results we can conclude that the adsorption of $\mathrm{Cr}(\mathrm{VI})$ was carried out at 50 , 75 , and $150 \mathrm{mg} / \mathrm{L}$ as Initial $\mathrm{Cr}(\mathrm{VI})$ ion concentration for a period of 5 hours at pH 5, 3 (T. aurea and $A$. серa), adsorbent: $10 \mathrm{~g} / \mathrm{l}$. T. aurea and $A$. cepa shows $75 \%$ and $85 \%$ removal at $150 \mathrm{mg} / \mathrm{L}$. the adsorbent amount from $5 \mathrm{~g} \cdot \mathrm{L}^{-1}$ to $15 \mathrm{~g} \cdot \mathrm{L}^{-1}$ with adsorbent $15 \mathrm{~g} \cdot \mathrm{L}^{-1}$ at the concentration of $50 \mathrm{mg} \cdot \mathrm{L}^{-1}$ the rercent removal was found to be 92 and 94 for $T$. aurea and $A$. cepa respectively. From the investigation we concluded that $T$. aurea maximum percentage removal was noticed at $\mathrm{pH}$, adsorbent: $10 \mathrm{mg} / \mathrm{L}$, shaking period: $75 \mathrm{rpm}$, initials concentration $150 \mathrm{mg} / \mathrm{L}$ were as maximum percentage removal for $A$. серa were obtained at $\mathrm{pH} \mathrm{3}$, adsorbent: $10 \mathrm{mg} / \mathrm{L}$, shaking period: $75 \mathrm{rpm}$, initials concentration: $150 \mathrm{mg} / \mathrm{L}$. Finally both Monocotyledon (Allium cepa) tunic and Dicotyledon plant (Tabebuia aurea) gave the better removal percentage in high concentration.

Table 6. Pseudo first-order rate constant for T. aurea.

\begin{tabular}{|c|c|c|c|c|c|c|c|c|}
\hline \multicolumn{9}{|c|}{ T. aurea } \\
\hline \multirow{2}{*}{$C_{0}(\mathrm{mg} / \mathrm{L})$} & \multirow{2}{*}{$C_{e}(\mathrm{mg} / \mathrm{L})$} & \multirow{2}{*}{$q_{e}(\mathrm{mg} / \mathrm{g})$} & \multicolumn{3}{|c|}{ First-order model } & \multicolumn{4}{c|}{ Second-order model } \\
\cline { 4 - 10 } & & & $K_{1}$ & $q_{e}(\mathrm{mg} / \mathrm{g})$ & $\mathrm{R}^{2}$ & $K_{2}$ & $q_{e}(\mathrm{mg} / \mathrm{g})$ & $\mathrm{R}^{2}$ \\
\hline 50 & 16.5 & 1.675 & 0.25 & 1.12 & 0.879 & 0.224 & 1.828 & 0.488 \\
\hline 75 & 21.5 & 1.425 & 0.64 & 1.12 & 0.918 & 1.505 & 1.464 & 0.965 \\
\hline 150 & 12.5 & 1.875 & 0.33 & 1.47 & 0.621 & 0.398 & 2.409 & 0.857 \\
\hline
\end{tabular}

Table 7. Pseudo first-order rate constant for A. cepa.

\begin{tabular}{|c|c|c|c|c|c|c|c|c|}
\hline \multicolumn{9}{|c|}{ A. cepa } \\
\hline \multirow{2}{*}{$C_{0}(\mathrm{mg} / \mathrm{L})$} & \multirow{2}{*}{$C_{e}(\mathrm{mg} / \mathrm{L})$} & \multirow{2}{*}{$q_{e}(\mathrm{mg} / \mathrm{g})$} & \multicolumn{3}{|c|}{ First-order model } & \multicolumn{4}{c|}{ Second-order model } \\
\cline { 4 - 10 } & & & $K_{1}$ & $q_{e}(\mathrm{mg} / \mathrm{g})$ & $\mathrm{R}^{2}$ & $K_{2}$ & $q_{e}(\mathrm{mg} / \mathrm{g})$ & $\mathrm{R}^{2}$ \\
\hline 50 & 20 & 1.5 & 0.20 & 2.31 & 0.838 & 0.004 & 7.19 & 0.007 \\
\hline 75 & 13.5 & 1.825 & 0.99 & 2.57 & 0.947 & 1.540 & 1.915 & 0.984 \\
\hline 150 & 7.5 & 2.125 & 0.56 & 2.40 & 0.878 & 10.86 & 2.398 & 0.909 \\
\hline
\end{tabular}




\section{Acknowledgements}

The authors are very grateful to Coimbatore Institute of Technology, Coimbatore for sponsoring this study through the TEQIP-PHASE II is gratefully acknowledged.

\section{References}

1. SARAVANAN N., KANNADASAN T., BASHA C. A., MANIVASAGAN V. Biosorption of textile dye using immobilized bacterial (Pseudomonas aeruginosa) and fungal (Phanerochate chrysosporium) cells. American J. of Environmental Science, 9, (4), 377, 2013.

2. SURESH G., BABU B.V. Removal of toxic metal $\mathrm{Cr}(\mathrm{VI})$ from aqueous solutions using sawdust as biosorbent: equilibrium, kinetics and regeneration studies. Chem. Eng. J. 150, 352, 2009.

3. BAILEY S E., OLIN T J., BRICKA R M. A review of potentially low-cost sorbents for heavy metals. [J]. Water Res., 33, (11), 2469, 1999.

4. NAGESWARA RAO L., PRABHAKAR G. Equilibrium and kinetic studies for biosorption system of chromium ions from aqueous solution using Ficus benghalensis L. powder. J. Chem. Pharm. Res. 3, (6), 73, 2011.

5. OUSTADAKIS P., AGATZINI-LEONARDOU S., TSAKIRIDIS P.E. Nickel and cobalt precipitation from sulphate leach liquor using $\mathrm{MgO}$ pulp as neutralizing agent. Min. Eng. 19, 1204, 2006.

6. IPEK U. Removal of $\mathrm{Ni}(\mathrm{II})$ and $\mathrm{Zn}$ (II) from an aqueous solution by reverse osmosis. Desalination 174, 161, 2005

7. KATSOU E., MALAMIS S., HARALAMBOUS K.J., LOIZIDOU M. Use of ultrafiltration membranes and aluminosilicate minerals for nickel removal from industrial wastewater. J. Membr. Sci. 360, 234, 2010.

8. AKBAL F., CAMCI S. Copper, chromium and nickel removal from metal plating wastewater by electrocoagulation. Desalination 269, 214, 2011.

9. CHENG Y., YAN F., HUANG F., CHU W., PAN D., CHEN Z., ZHENG J., YU M., LIN Z., WU Z. Bioremediation of $\mathrm{Cr}(\mathrm{VI})$ and immobilization as $\mathrm{Cr}(\mathrm{III})$ by Ochrobactrum anthropi. Environ. Sci. Technol. 44, (16), 6357, 2010.

10. DUNCAN J.R., BRADY D., STOLL A. Biosorption of heavy metal cations by non viable yeast cells. Environ. Technol. 15, 429, 1994.
11. IDOWU S.O., ONI S.O., ADEJUMO A.A. Biosorption of Chromium (VI) from Aqueous Solution By Biomass of Plantain (Musa Paradisiaca) Peel Residue. Afr J Med Phy, Biomed Eng \& Sc, 3, 22, 2011.

12. OVES M., SAGHIR KHAN M., ZAIDI A. Biosorption of heavy metals by Bacillus thuringiensis strain OSM29 originating from industrial effluent contaminated north Indian soil. Saudi Journal of Biological Sciences 20, 121, 2013.

13. FREUNDLICH H., HATFIELD H. Colloid and Capillary Chemistry. Methuen and Co. Ltd., London. 1926.

14. HAMADI N.K., CHEN X.D., FARID M.M., LU M.G.Q. Adsorption kinetics for the removal of chromium(VI) from aqueous solution by adsorbents derived from used tyres and sawdust. Chem. Eng. J. 84, (2), 95, 2001.

15. MOHANTY K., JHA M., MEIKAP B.C., BISWAS M.N. Biosorption of $\mathrm{Cr}(\mathrm{VI})$ from aqueous solutions by Eichhornia crassipes. Chem. Eng. J. 117, 71, 2006.

16. DADA A.O., OLALEKAN A.P., OLATUNYA A.M., DADA O. Langmuir, Freundlich, Temkin and DubininRadushkevich isotherms studies of equilibrium sorption of $\mathrm{Zn}^{2+}$ unto phosphoric acid modified rice husk. IOSR-JAC. J. Appl. Chem. 3, 38, 2012.

17. LANGMUIR I. The adsorption of gases on plane surfaces of glass, mica and platinum. J. Am. Chem. Soc., 40, (8), 1361, 1918.

18. PARK D., YUN Y.S., PARK J.M. Studies on hexavalent chromium biosorption by chemically-treated biomass of Ecklonia sp. Chemosphere 60, 1356, 2005.

19. PILLAI S.S., MANOHAR D., MULLASSERY., NOELINE B., FERNANDEZ., GIRIJA N., GEETHA P., KOSHY M. Biosorption of $\mathrm{Cr}(\mathrm{VI})$ from aqueous solution by chemically modified potato starch: Equilibrium and kinetic studies. Ecotoxicol. Environ. Saf. 92, 199, 2013.

20. GHOLAMI F., MAHVI A. H., OMRANI GH. A., NAZMARA SH. Removal of chromium (VI) from aqueous solution by Ulmus leaves. Iranian Journal of Environmental Health Science \& Engineering 3, (2), 97, 2006.

21. MAHVI A. H., NABIZADEH R., GHOLAMI F., KHAIRI A. Adsorption Of Chromium From Wastewater By Platanus Orientalis Leaves. Iranian Journal of Environmental Health Science \& Engineering 4, (3), 191, 2007.

22. ACHARYA J., SAHU J. N., SAHOO B. K., MOHANTY C. R., MEIKAP B. C. Removal of chromium (VI) from wastewater by activated carbon developed from Tamarind wood activated with zinc chloride. Chem. Eng. J. 150, 25, 2009. 
